\title{
Review
}

\section{Undoing work, rethinking community: A critique of the social function of work}

\author{
James A. Chamberlain \\ Ithaca, NY and London, 2018, 182 pp., \\ ISBN: 9781501714887
}

Contemporary Political Theory (2020) 19, S214-S216. https://doi.org/10.1057/s41296019-00327-x; Published online 21 May 2019

It is a regrettable and now tired truism of contemporary work life that 'what we do' increasingly determines 'who we are'. Our choice of employment - should we have such a choice - confers not just a sense of social status and recognition, but also, in a deep and perverse way, our self-worth. Today we work not simply to maintain an increasingly precarious livelihood, but also to find our 'true self', 'actualize our potential', and leave an indelible mark on the world. By extension, to fail at work or not work at all - equates less to any structural determinacy beyond our control and more to a personal sense of failure.

Following Freud, we might claim that work has become 'overdetermined': like the dream image, work takes on outsized significance in the psyche. And following Weber (2002), we might add that any connotation of work as a dream quickly devolves into a nightmare: 'The Puritan wanted to work in a calling; we are forced to do so' (p. 123). In line with these formidable thinkers, we find Chamberlain's Undoing Work, Rethinking Community, a succinct yet sophisticated assessment of work's preeminence in even our most progressive ideas for combating inequality and injustice. Whether they be regimes of flexibility, worker cooperatives, unconditional basic income, or renewed calls for socialism, all potentially suffer from an unexamined valorization of work that, according to Chamberlain, helps maintain work's exclusionary quality - namely, its tendency to elevate those who work from those who cannot. It follows from this that any real undoing of work, let alone any gesture toward a postwork society, can only happen alongside a rethinking of community. In other words, the 'hard work' of moving beyond work's preeminence requires us not only to fundamentally reexamine our social bonds and relations, but also to 'resist the idea of the community as a collective work' (p. 127).

The book opens with persuasive commentary on the value of work in contemporary society, and specifically on how the ideal of gainful employment infects popular discourse on both the political left and right. From there, the author sets the stage for demonstrating work's embeddedness in the way we conceive of

(C) 2019 Springer Nature Limited. 1470-8914 Contemporary Political Theory Vol. 19, S3, S214-S216 www.palgrave.com/journals 
society and especially community. Chapter 2 then serves as a spirited academic engagement with these themes through an extended dialogue with André Gorz's scholarship, which, while perhaps tangential to the uninformed reader, also moves beyond Gorz by demonstrating what Chamberlain calls "the inner workings of the work society: in particular, that it rests on an individualist social ontology and that the resultant society, understood as an association, constantly risks disintegration back to its constituent parts and needs a justifying principle to maintain its cohesion' (pp. 41-42). This key insight anticipates the eventual proposal for a truly 'social' social ontology, devoid of any principle acting as a common, unifying substance - including, of course, the unifying principle of work.

Building upon chapters 1 and 2, Chamberlain goes on to expose in chapter 3 how ostensibly liberating regimes of flexibility capitulate to a neoliberal imaginary, and particularly to the image of the hyper-individualized 'self-entrepreneur' that lies in direct proportion to an erosion of worker solidarity and union power. Although amply criticized elsewhere, such flexibility regimes are shown by Chamberlain to reassert the individualist social ontology that, in this instance, eclipses any collective obligation to care. More generally, the so-called 'crisis of care' scrutinized by Nancy Fraser, Evelyn Nakano Glenn, and Joan Tronto (among others) receives refreshingly novel attention by Chamberlain in this chapter as a key factor in any prospect of 'unworked' community.

Chapter 4 then tackles an increasingly popular and near-faddish proposal for mitigating 'the insecurity engendered by flexibilized labor markets' - namely, unconditional basic income (UBI) (p. 71). Aligned with his overall deflationary view of work, Chamberlain reveals how 'some supporters of the basic income seek to justify it on the grounds that it would further the related goals of full employment, labor market flexibility, and the end of welfare dependency, all with the implicit purpose of restoring the work society to its former glory' (p. 98). What good is UBI, Chamberlain seems to rhetorically ask, if it does not challenge the overall meaning and value of work?

Chapter 5 begins to fill in the author's vision of a postwork society grounded in a truly 'social' social ontology by building from, and arguably improving upon, proposals offered by Gorz and Michael Hardt and Antonio Negri. Each of the latter's proposals, however persuasive, suffers from the specter of work that in turn threatens to corrupt their respective views of community. As an alternative, Chamberlain draws upon the work Jean-Luc Nancy, and particularly his notion of the inoperative or 'unworked' community. Although admittedly abstract, Nancy's notion militates against an understanding of community as work, asserting instead that " "one does not produce [community]"; rather, "one experiences or one is constituted by it as the experience of finitude"' (p. 125). Put differently, far from imposing a narrative of community that squares experience or mends the exclusionary tendency of work through a sense of wholeness, Chamberlain prefers instead particularities, or what we might also call a Lacanian lack - a lack through

(C) 2019 Springer Nature Limited. 1470-8914 Contemporary Political Theory Vol. 19, S3, S214-S216 S215 
which various voices may speak, and a sharing of which might make space for the collective emergence of something new.

Chapter 6, while exceedingly brief, starts to instantiate this unworked community, which the author views as fundamentally at odds with capitalism. It is in this final chapter that the book offers its most speculative but also most inspiring lines of thought, all of which prove ripe for further inquiry. However, it is also in this final chapter that we are left wondering about our collective ability to maintain this shared lack beyond the exclusionary vectors of work. To be sure, the author seems willing to admit to a more basic human tendency to exclude, despite going a long way in

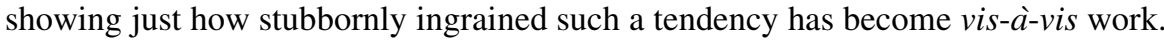
But just how we exclude is not (or not solely) a problem of the ideology of work per se, but of human psychology - and specifically our unconscious tendency to split off unwanted aspects of ourselves and project them onto denigrated, excluded others. Psychoanalyst Melanie Klein's (1946) discovery of the paranoid-schizoid position, for instance, which first emerges in infancy when we necessarily fail to grasp the full complexity of our emotions or accept the existence of good and bad in a single object, serves as a humbling reminder of just what we are up against in building any community beyond work. And arguably, it is this deeper unconscious tendency to tear apart reality - and ourselves - that we can never fully undo, but rather from a psychoanalytic perspective and perhaps ironically, must constantly 'work through'.

But far more important than any downplaying of humanity's pathos, Undoing Work, Rethinking Community offers a concerted challenge to work writ large that is both admirable and exemplary. Chamberlain's promise of community, moreover, sets the right balance of critique with concern to move the debate forward. Scholars of work in political science, philosophy, sociology and psychology will all find something of value in the book, as well as a lay audience increasingly attuned to work's perils.

\section{References}

Klein, M. (1946). Notes on Some Schizoid Mechanisms. International Journal of Psychoanalysis, 27, 99-110.

Weber, M. 2002. The Protestant Ethic and the Spirit of Capitalism. trans. T. Parsons. New York: Routledge.

Publisher's Note Springer Nature remains neutral with regard to jurisdictional claims in published maps and institutional affiliations. 